\title{
High Ethanol Consumption and Low Sensitivity to Ethanol-Induced Sedation in Protein Kinase A-Mutant Mice
}

\author{
Todd E. Thiele, ${ }^{1}$ Brandon Willis, ${ }^{2}$ Julia Stadler, ${ }^{2}$ James G. Reynolds, ${ }^{1}$ Ilene L. Bernstein, ${ }^{1}$ and \\ G. Stanley McKnight ${ }^{2}$ \\ 1Department of Psychology and the Alcohol and Drug Abuse Institute and ${ }^{2}$ Department of Pharmacology, University of \\ Washington, Seattle, Washington 98195
}

Both in vitro and in vivo evidence indicate that cAMPdependent protein kinase (PKA) mediates some of the acute and chronic cellular responses to alcohol. However, it is unclear whether PKA regulates voluntary alcohol consumption. We therefore studied alcohol consumption by mice that completely lack the regulatory $\| \beta(\mathrm{R} \| \beta)$ subunit of PKA as a result of targeted gene disruption. Here we report that RII $\beta$ knockout mice (RII $\beta-/-)$ showed increased consumption of solutions containing 6,10 , and $20 \%(\mathrm{v} / \mathrm{v})$ ethanol when compared with wild-type mice $(\mathrm{RII} \beta+/+)$. On the other hand, RII $\beta-/-$ mice showed normal consumption of solutions containing either sucrose or quinine. When compared with wild-type mice, the RII $\beta-/-$ mice were found to be less sensitive to the sedative effects of ethanol as measured by more rapid recovery from ethanol-induced sleep, even though plasma ethanol concentrations did not differ significantly from those of controls. Finally, both $\mathrm{RI} \beta$ - and catylatic subunit $\beta 1$-deficient mice showed normal voluntary consumption of ethanol, indicating that increased ethanol consumption is not a general characteristic associated with deletion of PKA subunits. These data demonstrate a role for the RII $\beta$ subunit of PKA in regulating voluntary consumption of alcohol and sensitivity to the intoxication effects that are produced by this drug.

Key words: alcohol consumption; sedation; PKA; knock-out; regulatory subunit; intracellular signaling
Many neurotransmitters and hormones transduce their signal into a cell by activating G-protein-coupled receptors that modulate adenylyl cyclase; this changes intracellular cAMP levels, which subsequently alters cAMP-dependent protein kinase (PKA) activity. PKA comprises a holoenzyme consisting of a regulatory (R) subunit homodimer and two catalytic (C) subunits (Brandon et al., 1997). In mice there are four $\mathrm{R}$ genes (encoding $\mathrm{RI} \alpha, \mathrm{RI} \beta$, $\mathrm{RII} \alpha$, and $\mathrm{RII} \beta$ ) and two $\mathrm{C}$ genes $(\mathrm{C} \alpha$ and $\mathrm{C} \beta)$, expressed in tissue-specific patterns (McKnight, 1991). The cAMP-PKA system has been implicated in adipose regulation (Cummings et al., 1996), neural plasticity associated with learning and memory (Kandel and Schwartz, 1982; Skoulakis et al., 1993; Connolly et al., 1996; Goodwin et al., 1997; Villacres et al., 1998; Wong et al., 1999), drug tolerance and dependence (Self and Nestler, 1995; Moore et al., 1998; Andretic et al., 1999; Yoshimura and Tabakoff, 1999), and sensitization in nociception (Taiwo and Levine, 1991). We have produced RII $\beta-/-$ mice by gene targeting (Brandon et al., 1995a, 1998). These mice grow and reproduce similarly to wild-type mice and have a normal life span. However, they exhibit diminished white adipose tissue and resistance to dietinduced obesity (Cummings et al., 1996). Consistent with the observation that RII $\beta$ is the most highly expressed R subunit in basal ganglia-associated circuitry (Cadd and McKnight, 1989; Glantz et al., 1992), we have found that RII $\beta-/-$ mice have deficits in complex motor behavior (Brandon et al., 1998) and are

\footnotetext{
Received Dec. 20, 1999; revised March 14, 2000; accepted March 15, 2000.

This work was supported by National Institutes of Health Grants AA00258 (T.E.T.), NS37040 (I.L.B.), and GM32875 (G.S.M.) and by a generous donation from the Brunstad family to T.E.T.

Correspondence should be addressed to Todd E. Thiele, Department of Psychology, Box 351525, University of Washington, Seattle, WA 98195. E-mail: thiele@u.washington.edu.

Copyright $(\subset 2000$ Society for Neuroscience $\quad 0270-6474 / 00 / 200001-\bullet \$ 15.00 / 0$
}

resistant to haloperidol-induced gene expression and catalepsy (Adams et al., 1997).

There is increasing evidence that PKA is involved with mediating some of the acute and chronic cellular responses to ethanol (Diamond and Gordon, 1997). For example, chronic administration of ethanol has been found to cause significant increases in cAMP levels and PKA activity in the nucleus accumbens of rats (Ortiz et al., 1995). Furthermore, in vitro studies revealed that 200 mM ethanol caused translocation of the $\mathrm{C} \alpha$ subunit of PKA from the Golgi area to the nucleus in $\sim 75 \%$ of exposed cells, and that $\mathrm{C} \alpha$ remained in the nucleus as long as ethanol was present (Dohrman et al., 1996). However, although it is clear that ethanol influences PKA activity, it is not clear whether PKA activity is involved in regulating voluntary ethanol consumption. To address this question, we studied ethanol consumption and sensitivity to the acute effects of ethanol in $\operatorname{RII} \beta-/-$ mice to determine whether ethanol-seeking behavior and the neurobiological effects of ethanol are also influenced by genetic alterations in PKA activity.

This article is published in The Journal of Neuroscience, Rapid Communications Section, which publishes brief, peerreviewed papers online, not in print. Rapid Communications are posted online approximately one month earlier than they would appear if printed. They are listed in the Table of Contents of the next open issue of JNeurosci. Cite this article as: JNeurosci, 2000, 0:RC75 (1-6). The publication date is the date of posting online at www.jneurosci.org.

http://www.jneurosci.org/cgi/content/full/4193 


\section{MATERIALS AND METHODS}

Animals. The disruption of the RII $\beta$ gene by homologous recombination in embryonic stem cells from $129 \mathrm{SvJ}$ mice has been described (Brandon et al., 1998). Chimeras were bred with C57BL/6 mice to obtain heterozygotes $(50 \% 129 \mathrm{SvJ} \times 50 \% \mathrm{C} 57 \mathrm{BL} / 6)$. These heterozygotes were backcrossed with C57BL/6 mice to yield RII $\beta+/-$ mice on a $98 \%$ C57BL $/ 6$ genetic background. These mice were then bred with $129 \mathrm{SvJ}$ mice, and the F2 mice from this cross yielded RII $\beta-/-$ mice and wild-type $(\mathrm{RII} \beta+/+)$ littermate mice $(\sim 50 \% 129 \mathrm{SvJ} \times 50 \% \mathrm{C} 57 \mathrm{BL} / 6)$, which were used in the present studies. Studies used an approximately equal number of male and female RII $\beta-/-$ and $\operatorname{RII} \beta+/+$ mice. Each study described below used naïve mice. Mice were individually housed in plastic mouse cages with ad libitum access to standard rodent chow (Teklad; Harlan, Madison, WI) and water throughout the experiments. The colony room was maintained at $\sim 22^{\circ} \mathrm{C}$ with a $12 \mathrm{hr}$ light/dark cycle.

Alcohol intake test. Throughout the experiments, fluid intake, food intake, and body weight measures were assessed every $2 \mathrm{~d}$. RII $\beta-/-(n=$ $12)$ and wild-type $(n=12)$ mice were habituated in their home cage to drinking from two bottles containing plain water over $6 \mathrm{~d}$. Mice were then given $24 \mathrm{hr}$ access to two bottles, one containing plain water and the other containing ethanol in water. The concentration of ethanol (v/v) was increased every $8 \mathrm{~d}$; mice received 3, 6, 10, and finally $20 \%$ ethanol over the course of the experiment. The positions of the bottles were changed every $2 \mathrm{~d}$ to control for position preferences. These same procedures were used with $\mathrm{RI} \beta-/-(n=12)$ and $\mathrm{RI} \beta+/+(n=12)$ mice and with $\mathrm{C} \beta 1-/-(n=14)$ and $\mathrm{C} \beta 1+/+(n=14)$ mice. Average ethanol consumption per day was obtained for each ethanol concentration. To obtain a measure of ethanol consumption that corrected for individual differences in mouse size, grams of ethanol consumed per kilogram of body weight per day were calculated for each mouse. As a measure of relative ethanol preference, ethanol preference ratios were calculated at each ethanol concentration by dividing total ethanol solution consumed by total fluid (ethanol plus water) consumption. Two-way, $2 \times 4$ (genotype $\times$ concentration) repeated measures ANOVAs were used for statistical examination of the data.

Test for sensitivity ethanol-induced sedation. RII $\beta-/-(n=11)$ and $\mathrm{RII} \beta+/+(n=9)$ mice were removed from their home cage and given an intraperitoneal injection of ethanol $(4.0 \mathrm{gm} / \mathrm{kg} ; 20 \%$, w/v, mixed in isotonic saline). At the onset of ethanol-induced sedation each mouse was placed on its back into a plastic U-shaped trough. The time (minutes) that elapsed between the ethanol injection and when the mouse could right itself onto all four paws, three times within a $30 \mathrm{sec}$ interval, was used as the index of time to regain the righting reflex. These data were analyzed with a one-way (genotype) ANOVA.

Sucrose and quinine consumption test. RII $\beta-/-(n=13)$ and $\operatorname{RII} \beta+/+$ $(n=12)$ mice were habituated in their home cage to drinking from two bottles containing plain water for $6 \mathrm{~d}$. Over the next $8 \mathrm{~d}$, mice were given plain water in one bottle and sucrose or quinine in the other bottle. The compounds were presented in the following order: sucrose solutions (1.70 and $4.25 \%$ ) followed by quinine solutions ( 0.03 and $0.10 \mathrm{~mm})$. Mice had $48 \mathrm{hr}$ access to each solution, and the position of the solution was counterbalanced between animals. Milliliters of solution consumed per kilogram of body weight per day were calculated for each mouse. Data collected with each taste solution were analyzed separately with two-way, $2 \times 2$ (genotype $\times$ concentration) repeated measures ANOVA.

Kinase assay. Kinase activity was assayed on cell homogenates as described elsewhere (Clegg et al., 1987) using Kemptide (Kemp et al., 1977) as a substrate in the presence or absence of $5 \mu \mathrm{M}$ cAMP. Residual activity in the presence of $4 \mu \mathrm{g} / \mathrm{ml}$ protein kinase inhibitor peptide was subtracted. For each brain region examined, samples were collected from two or three separate animals. In some cases, kinase activity was assessed after injection of ethanol or an equal volume of isotonic saline. Mice were given an intraperitoneal injection of $4.0 \mathrm{gm} / \mathrm{kg}$ ethanol $(20 \%, \mathrm{w} / \mathrm{v})$ and returned to their home cages. Four hours later, mice were given an intraperitoneal injection of $2.0 \mathrm{gm} / \mathrm{kg}$ ethanol. Six hours after the first injection, mice were rapidly anesthetized with $\mathrm{CO}_{2}$, and their brains were removed for kinase assays. Based on our plasma ethanol data, we estimated that these mice would have plasma ethanol levels of $\geq 150$ $\mathrm{mg} / \mathrm{dl}$ during the $6 \mathrm{hr}$ of ethanol exposure.

Plasma ethanol concentrations. $\operatorname{RII} \beta-/-(n=3)$ and $\operatorname{RII} \beta+/+(n=3)$ mice were given an intraperitoneal injection of ethanol $(4.0 \mathrm{gm} / \mathrm{kg} ; 20 \%$, $\mathrm{w} / \mathrm{v}$, mixed in isotonic saline) and immediately returned to their home cage. One-half, 2 , and $4 \mathrm{hr}$ after ethanol injection, $\sim 30 \mu \mathrm{l}$ of blood was collected from each mouse via the hindlimb saphenous vein. Plasma ethanol levels were determined via spectrophotometic methods (Enzy-
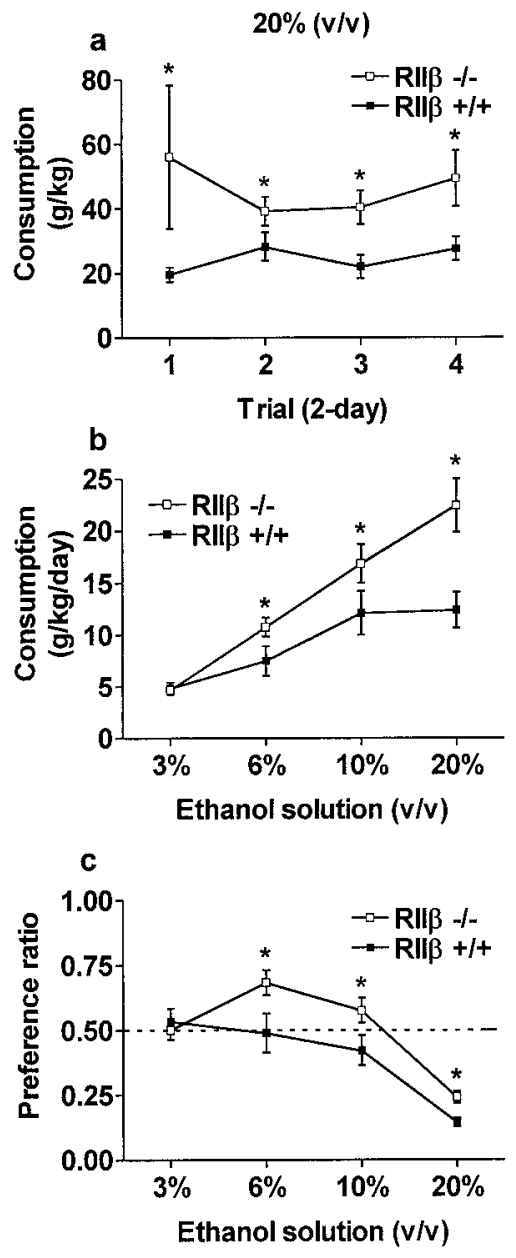

Figure 1. Consumption of ethanol by mutant mice lacking the RII $\beta$ subunit of PKA (RII $\beta-/-)$ and wild-type control mice $(\mathrm{RII} \beta+/+)$ maintained on a $129 \mathrm{SvJ} \times \mathrm{C} 57 \mathrm{BL} / 6$ hybrid background. $a$, Consumption (grams per kilogram) of a $20 \%$ ethanol solution. $b$, Consumption (grams per kilogram per day) at each ethanol solution (8-d average). $c$, Ethanol preference ratios (volume of ethanol consumed/total fluid consumed) as a measure of relative ethanol preference. All values reported as mean \pm SEM. ANOVAs indicated that the RII $\beta-/-$ mice drank significantly more ethanol than $\operatorname{RII} \beta+/+$ mice. $\operatorname{RII} \beta-/-$ versus $\operatorname{RII} \beta+/+,{ }^{*} p<0.05$.

matic Determination of Alcohol Test; Sigma, St. Louis, MO) and calculated as milligrams per deciliter. A two-way, $2 \times 3$ (genotype $\times$ time) repeated measures ANOVA was used to analyze the data.

\section{RESULTS}

\section{RII $\beta-/-$ mice drink high amounts of solutions containing ethanol}

The RII $\beta-/-$ mice consumed significantly more 6,10 , and $20 \%$ ethanol solution when compared with wild-type littermate control mice (Fig. 1a,b), drinking nearly twice as much of the $20 \%$ ethanol solution. We expressed consumption of ethanol relative to total fluid consumption (ethanol preference ratio). RII $\beta-/-$ mice showed a higher intake of ethanol and preferred ethanol to water (preference ratios $>0.50$ ) during access to the 6 and $10 \%$ ethanol solutions (Fig. 1c). Although there were no significant differences between genotypes in measures of average food intake $\left(\mathrm{RII} \beta-/-\right.$ mice, $179.81 \pm 7.05 \mathrm{gm} \cdot \mathrm{kg}^{-1} \cdot \mathrm{d}^{-1} ; \mathrm{RII} \beta+/+$ mice, $\left.172.02 \pm 3.29 \mathrm{gm} \cdot \mathrm{kg}^{-1} \cdot \mathrm{d}^{-1}\right)$ or average water consumption $\left(\operatorname{RII} \beta-/-\right.$ mice, $165.56 \pm 15.3 \mathrm{gm} \cdot \mathrm{kg}^{-1} \cdot \mathrm{d}^{-1} ; \mathrm{RII} \beta+/+$ mice, $\left.180.07 \pm 12.29 \mathrm{gm} \cdot \mathrm{kg}^{-1} \cdot \mathrm{d}^{-1}\right)$, consistent with previous 

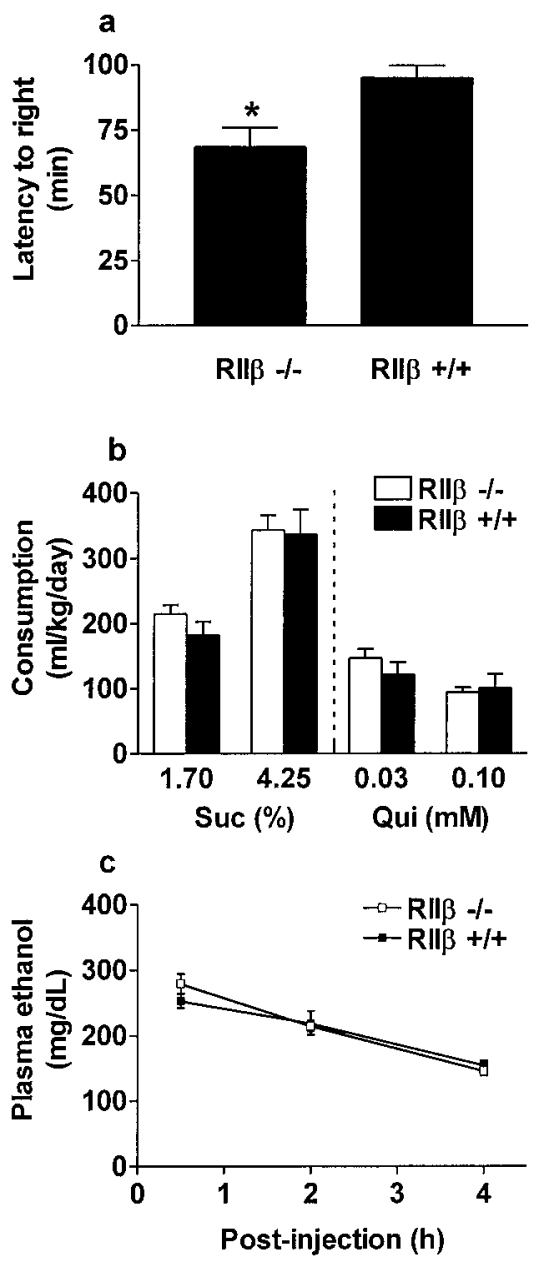

Figure 2. Measures of acute sensitivity to the sedative effects of ethanol, consumption of nonalcoholic tastants, and plasma ethanol levels (mean \pm SEM). $a$, Time to regain the righting reflex (minutes) after injection of ethanol $(4.0 \mathrm{gm} / \mathrm{kg}$; i.p.). $b$, Consumption (milliliters per kilograms per day) of solutions containing either sucrose (Suc) or quinine (Qui). c, Plasma ethanol concentration (milligrams per deciliter) either 1 or $3 \mathrm{hr}$ after ethanol injection $(4.0 \mathrm{gm} / \mathrm{kg}$; i.p). ANOVAs indicated that RII $\beta-/-$ mice recovered from ethanol-induced sedation significantly sooner than $\mathrm{RII} \beta+/+$ mice. On the other hand, RII $\beta-/-$ and $\mathrm{RII} \beta+/+$ mice did not differ significantly in consumption of nonalcoholic tastants or plasma ethanol levels. RII $\beta-/-$ versus $\operatorname{RII} \beta+/+,{ }^{*} p<0.05$.

reports, RII $\beta-/-$ mice showed significantly lower average body weight $(\mathrm{RII} \beta-/-$ mice, $24.72 \pm 0.75 \mathrm{gm}$; RII $\beta+/+$ mice, $27.89 \pm$ $1.1 \mathrm{gm} ; p<0.05)$.

\section{RII $\beta-/-$ mice are resistant to} ethanol-induced sedation

Examples from both human and animal research indicate that high levels of ethanol drinking are often associated with resistance to the physiological effects of this drug (Schuckit, 1986, 1988, 1994; Kurtz et al., 1996; Thiele et al., 1998). We therefore determined whether RII $\beta-/-$ mice were resistant to the sedative and hypnotic effects of ethanol. The RII $\beta-/-$ mice were resistant to the sedative effects of ethanol, regaining their righting reflex $\sim 25$ min sooner than wild-type mice (Fig. $2 a$ ).

\section{Normal consumption of nonalcoholic tastants and ethanol metabolism in RII $\beta-/-$ mice}

We determined whether increased ethanol consumption and resistance to the acute effects of ethanol in the RII $\beta-/-$ mice might be unrelated to the pharmacological effects of ethanol. To determine whether genotypes show general differences in taste preference, we tested separate groups of mice with sucrose and quinine solutions, using the same protocol as above. We used these tastants because previous research has indicated that rodents perceive the taste of alcohol as a sweet-bitter compound (Kiefer et al., 1990). There were no significant differences between genotypes in voluntary consumption of these sweet and bitter solutions (Fig. $2 b$ ). Thus increased consumption of ethanol in $\operatorname{RII} \beta-/-$ mice did not extend to other flavored solutions. Additionally, because ingestion of food and sucrose solutions, both of which contain calories, did not differ between the genotypes, increased intake of ethanol by $\operatorname{RII} \beta-/-$ mice does not appear to be calorie-driven. It was also possible that the RII $\beta-/-$ mice showed high ethanol consumption and resistance because of an increased rate of alcohol metabolism. However, this does not appear likely, because the RII $\beta-/-$ and wild-type mice did not differ in plasma ethanol concentrations either 1 or $3 \mathrm{hr}$ after injection (Fig. 2c).

\section{CAMP-stimulated PKA activity is reduced in RII $\beta-/-$ mice}

Reductions in cAMP-stimulated PKA activity have been identified in several brain regions of the $\operatorname{RII} \beta-/-$ mice, including the cortex and the striatum (Adams et al., 1997; Brandon et al., 1998). Although the genotypes did not differ in PKA activity in the absence of cAMP, here we show a reduction in cAMP-stimulated PKA activity in the nucleus accumbens, the amygdala, the hippocampus, and the hypothalamus of $\operatorname{RII} \beta-/-$ mice (Fig. 3). Although we cannot conclude from the present data which, if any, of these regions are involved with altered ethanol consumption and sensitivity in RII $\beta-/-$ mice, each of these brain regions has been shown to be a target for ethanol and may be involved with mediating neurobiological effects produced by this drug (Ryabinin et al., 1997). Finally, when compared with saline injection, ethanol injection did not alter either basal or cAMP-stimulated PKA activity in the amygdala (Fig. $3 e, f$ ).

\section{Normal ethanol consumption in $\mathbf{R} \mathbf{\beta}$ - and C $\boldsymbol{\beta} 1$-deficient mice}

To determine whether increased ethanol consumption is a general characteristic associated with deletion of PKA subunits, we assessed voluntary ethanol consumption in two other PKA subunit knock-out mice that show normal development and reproduction (Brandon et al., 1995b; Guthrie et al., 1997). RI $\beta$ is expressed exclusively in neurons, whereas $C \beta 1$ (a splice variant of $\mathrm{C} \beta$ ) is expressed in all tissues. The $\mathrm{C} \beta$ gene also contains two neuron-specific promoters that are highly expressed in the basal ganglia giving rise to $C \beta 2$ and $C \beta 3$ proteins, and these transcripts are unaffected in the $\mathrm{C} \beta 1$ knock-out mice. Relative to their wild-type littermates, neither the $\mathrm{RI} \beta$ nor the $\mathrm{C} \beta 1$ knock-out mice drank increased amounts of solutions containing ethanol (Fig. 4). Initial data also indicate that deletion of the RII $\alpha$ gene does not cause increased ethanol consumption (data not presented). Thus, increased ethanol intake appears to be specific to $\operatorname{RII} \beta$ knock-out mice.

\section{DISCUSSION}

Here we show that the RII $\beta$ subunit of PKA is critically involved with regulating both voluntary ethanol consumption and sensitivity to the acute intoxicating effects of this drug. Increased consumption of ethanol in RII $\beta-/-$ mice does not appear to be related to the taste and/or caloric properties of ethanol, because 
Figure 3. Kinase assay with homogenates of the indicated brain regions from RII $\beta-/-$ and RII $\beta+/+$ mice (mean \pm SEM). Phosphorylation of PKA substrate Kemptide was assayed in the presence $(+c A M P)$ or absence (basal) of $5 \mu \mathrm{M}$ cAMP. Although basal activity did not differ between the genotypes, the data indicate that $\operatorname{RII} \beta-/-$ mice have reduced cAMP-stimulated PKA activity in each brain region examined. Furthermore, $6 \mathrm{hr}$ exposure to ethanol did not alter PKA activity in $\operatorname{RII} \beta-/-$ or $\operatorname{RII} \beta+/+$ mice $(e, f)$.
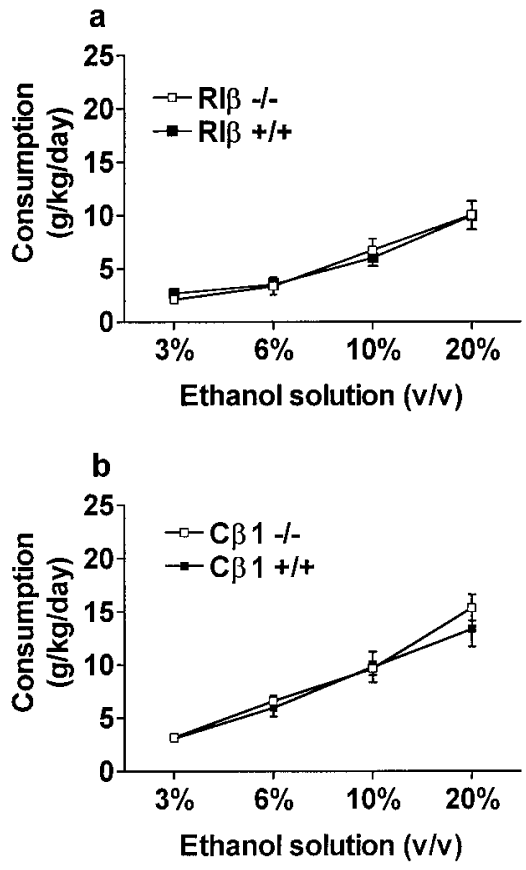

Figure 4. Consumption of solutions containing ethanol (grams per kilogram per day) in mutant mice lacking either the $\operatorname{RI} \beta(\operatorname{RI} \beta-/-)$ subunit of PKA $(a)$ or the C $\beta 1(\mathrm{C} \beta 1-/-)$ subunit of PKA $(b)$ and their respective wild-type controls. Values are reported as mean \pm SEM. With each mutant model, knock-out and wild-type mice did not differ significantly in ethanol consumption at each concentration tested.

these mice showed normal consumption of solutions containing either sucrose or quinine and normal food intake. Furthermore, increased consumption and resistance to the acute effects of
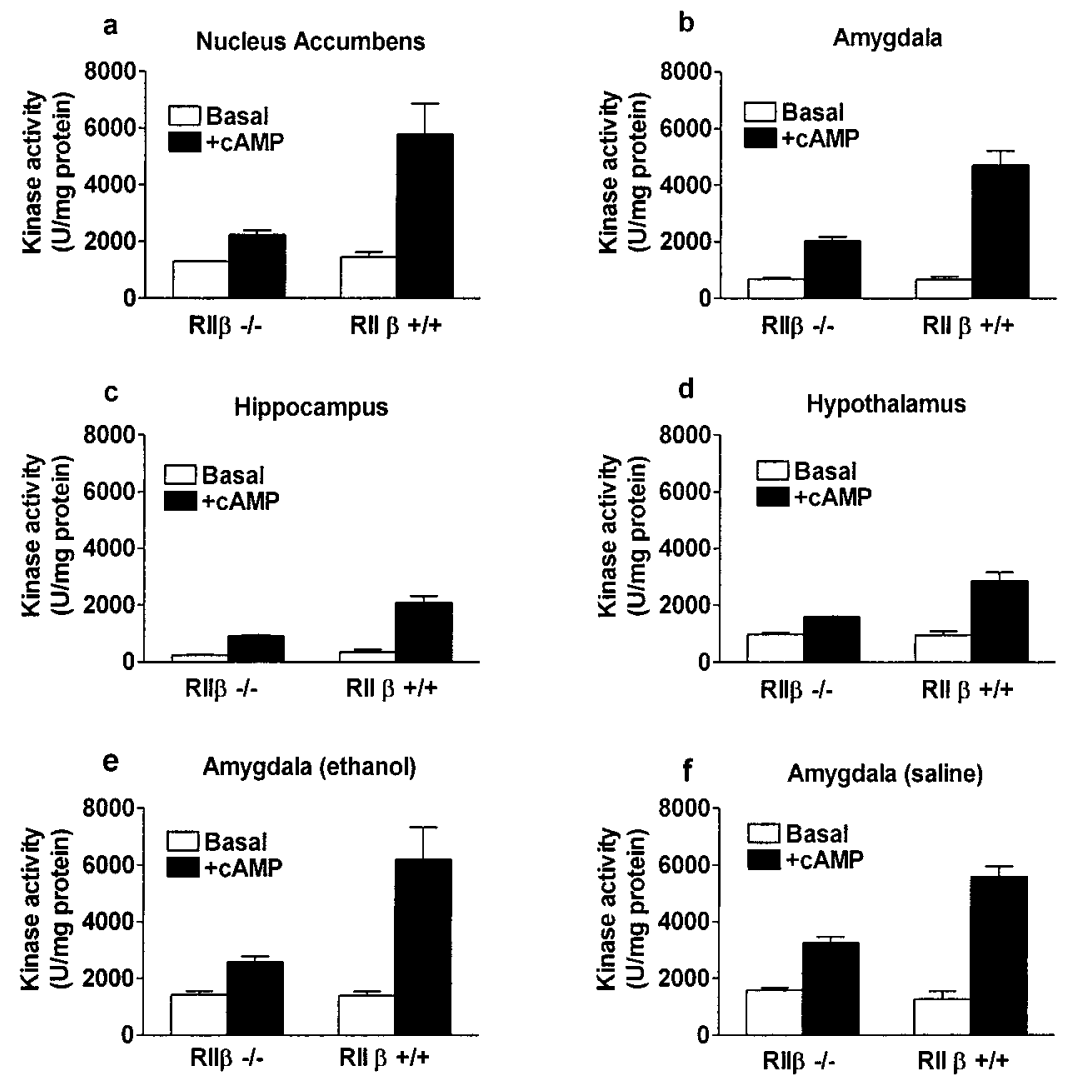

ethanol are not related to increased ethanol metabolism, because RII $\beta-/-$ and RII $\beta+/+$ mice did not differ in plasma ethanol levels. Previous research found that C57BL/6 mice that voluntarily drank from a $10 \%(\mathrm{v} / \mathrm{v})$ ethanol solution during a $24 \mathrm{hr}$ period consumed an average of $5 \mathrm{gm} / \mathrm{kg}$ ethanol and reached pharmacologically significant peak blood ethanol levels of $\sim 0.125 \%$ (Dole and Gentry, 1984). Because mice in the present study drank an average of $12-17 \mathrm{gm} \cdot \mathrm{kg}^{-1} \cdot \mathrm{d}^{-1}$ during access to the $10 \%$ ethanol solution, it may be assumed that they obtained peak blood alcohol concentrations of $\geq 0.125 \%$ during periods of peak consumption. Thus, we concluded that RII $\beta-/-$ mice have altered sensitivity to the pharmacological effects that are produced by ethanol. Importantly, these data present the first direct evidence that PKA signaling is involved with ethanol-seeking behavior.

PKA activation occurs when cAMP binds to the $\mathrm{R}$ subunit of the PKA complex, liberating catalytically active $C$ subunits, which diffuse throughout the cell and phosphorylate nearby proteins; the $\mathrm{C}$ subunits then translocate to the nucleus and regulate gene expression (Brandon et al., 1997). Because RII $\beta$ is the major R subunit in many brain regions, including the striatum, the nucleus accumbens, and the amygdala, and because increases in RI $\alpha$ and $\mathrm{RI} \beta$ do not compensate fully for the loss of RII $\beta$ (Amieux et al., 1997; Brandon et al., 1998), an increased proportion of active C subunits are chronically unregulated in $\operatorname{RII} \beta-/-$ mice. Thus, the absence of RII $\beta$ produces a state of constitutive PKA activation in RII $\beta-/-$ mice, even in the absence of cAMP activation. We suggest that it is this chronic PKA activation that promotes increased ethanol consumption and resistance to the acute effects of ethanol in RII $\beta-/-$ mice. However, in addition to regulating $\mathrm{C}$ subunit activity, $\mathrm{R}$ subunits also protect $\mathrm{C}$ subunits from proteolysis (Hemmings, 1986); thus unbound (i.e., active) $\mathrm{C}$ subunits are more rapidly degraded in $\mathrm{RII} \beta-/-$ mice, leading to dramatic 
decreases in steady-state levels of both $\mathrm{C} \alpha$ and $\mathrm{C} \beta$ (Brandon et al., 1998). The reduction of total PKA activity in striatum, amygdala, and hippocampus reflects this destabilization of $\mathrm{C}$ subunit because there is no change in mRNA levels for $\mathrm{C}$ subunit in RII $\beta-/-$ mice (our unpublished data). In summary, the effects of the RII $\beta$ mutation on PKA activity are complex, resulting in chronic release of active $\mathrm{C}$ subunit, which is then downregulated by proteolysis, resulting in lower total cAMP-stimulated PKA activity in specific brain regions.

If the increase in voluntary ethanol consumption is the result of chronic PKA activity, then deletion of other PKA subunits that do not result in altered PKA activity should be associated with normal physiological and behavioral responses to ethanol. Furthermore, other treatments expected to chronically increase basal cAMP levels and PKA activity should also lead to increased ethanol intake and/or reduced sensitivity to ethanol, whereas the opposite (decreased intake and increased sensitivity) would be expected of treatments that produce chronic reductions in cAMP levels and PKA activity. In fact, deletion of the RI $\beta$ subunit of PKA is associated with compensation by $\mathrm{RI} \alpha$ in the brain, and there are no detectable changes in $\mathrm{C}$ subunit levels or total PKA activity (Brandon et al., 1995b; Amieux et al., 1997); we have shown that RI $\beta-/-$ mice drink normal amounts of ethanol. Deletion of the $\mathrm{C} \beta 1$ subunit also has little impact on PKA activity (Huang et al., 1995), and C $\beta 1-/-$ mice also show normal ethanol intake. More severe deficits in $\mathrm{C}$ subunit activity might be expected to reduce ethanol consumption, and we will test this hypothesis by targeted disruption of the neural-specific $C \beta 2,3$ isoforms.

Recently, it was shown that mutant mice that lack neuropeptide Y (NPY) are resistant to ethanol-induced sedation and show high levels of ethanol consumption. On the other hand, transgenic mice that overexpress NPY were found to be more sensitive to ethanol-induced sedation and drank little ethanol (Thiele et al., 1998). Because NPY receptors are coupled to $G_{i}$ proteins that inhibit adenylate cyclase, removal of this peptide could allow a chronic increase in cAMP levels and activation of PKA. The opposite effect would be expected in transgenic mice overexpressing NPY. Another example suggesting a connection between ethanol sensitivity and cAMP has been reported in studies of the inactivation of the Drosophila amnesiac gene. Amnesiac encodes a secreted neuropeptide that stimulates cAMP production, and inactivation of this gene renders flies more sensitive to ethanolinduced sedation (Moore et al., 1998). Removal of an excitatory neuromodulator should cause chronic reductions in cAMP levels and PKA activity consistent with the hypothesized relationship between CAMP and PKA signaling and sensitivity to the intoxicating effects of ethanol. Together, these data suggest that resistance to the acute effects of ethanol and the rate of voluntary ethanol consumption could be linked to cAMP levels and activation of PKA.

There is increasing evidence indicating that high levels of ethanol drinking are often associated with resistance to the intoxicating effects produced by this drug. For example, rats that have been selectively bred for high ethanol consumption recover from ethanol-induced sedation significantly sooner than those rats that have been selectively bred for low alcohol drinking (Kurtz et al., 1996). As discussed above, there is an inverse relationship between ethanol consumption and the degree of sensitivity to the sedative effects of this drug in NPY knock-out and NPY-overexpressing mice (Thiele et al., 1998). Interestingly, this relationship is also found in human research. Sons and daughters of alcoholics are less sensitive to the biochemical, motor, and perceptual changes induced by intoxicating levels of ethanol relative to children without a family history of alcoholism. Furthermore, these children have an increased risk for developing alcoholism (Schuckit, 1994). Here we demonstrate another example of this relationship, because $\operatorname{RII} \beta-/-$ mice drink large amounts of ethanol and are also resistant to the intoxicating effects of the drug.

We show that the RII $\beta$ subunit of PKA is important for regulating ethanol intake and sensitivity to the acute effects of ethanol. Because mutation of either the $\mathrm{RI} \beta$ or $\mathrm{C} \beta 1$ genes does not influence ethanol ingestion, increased ethanol consumption does not appear to be a general characteristic associated with deletion of PKA subunits. Rather, it is likely that RII $\beta-/-$ mice drink more ethanol because normal PKA activity is disrupted in brain regions involved with mediating ethanol reward. It will be important to determine where the $\operatorname{RII} \beta$ subunit acts to regulate ethanol consumption.

\section{REFERENCES}

Adams MR, Brandon EP, Chartoff EH, Idzerda RL, Dorsa DM, McKnight GS (1997) Loss of haloperidol induced gene expression and catalepsy in protein kinase A-deficient mice. Proc Natl Acad Sci USA 94:12157-12161.

Amieux PS, Cummings DE, Motamed K, Brandon EP, Wailes LA, Le K, Idzerda RL, McKnight GS (1997) Compensatory regulation of RIalpha protein levels in protein kinase A mutant mice. J Biol Chem 272:3993-3998.

Andretic R, Chaney S, Hirsh J (1999) Requirement of circadian genes for cocaine sensitization in Drosophila. Science 285:1066-1068.

Brandon EP, Gerhold KA, Qi M, McKnight GS, Idzerda RL (1995a) Derivation of novel embryonic stem cell lines and targeting of cyclic AMP-dependent protein kinase genes. Recent Prog Horm Res 50:403-408.

Brandon EP, Zhuo M, Huang YY, Qi M, Gerhold KA, Burton KA, Kandel ER, McKnight GS, Idzerda RL (1995b) Hippocampal longterm depression and depotentiation are defective in mice carrying a targeted disruption of the gene encoding the RI beta subunit of cAMPdependent protein kinase. Proc Natl Acad Sci USA 92:8851-8855.

Brandon EP, Idzerda RL, McKnight GS (1997) PKA isoforms, neural pathways, and behaviour: making the connection. Curr Opin Neurobiol 7:397-403.

Brandon EP, Logue SF, Adams MR, Qi M, Sullivan SP, Matsumoto AM, Dorsa DM, Wehner JM, McKnight GS, Idzerda RL (1998) Defective motor behavior and neural gene expression in RIIbeta-protein kinase A mutant mice. J Neurosci 18:3639-3649.

Cadd G, McKnight GS (1989) Distinct patterns of cAMP-dependent protein kinase gene expression in mouse brain. Neuron 3:71-79.

Clegg CH, Correll LA, Cadd GG, McKnight GS (1987) Inhibition of intracellular cAMP-dependent protein kinase using mutant genes of the regulatory type I subunit. J Biol Chem 262:13111-13119.

Connolly JB, Roberts IJ, Armstrong JD, Kaiser K, Forte M, Tully T, O'Kane CJ (1996) Associative learning disrupted by impaired Gs signaling in Drosophila mushroom bodies. Science 274:2104-2107.

Cummings DE, Brandon EP, Planas JV, Motamed K, Idzerda RL, McKnight GS (1996) Genetically lean mice result from targeted disruption of the RII beta subunit of protein kinase A. Nature 382:622-626.

Diamond I, Gordon A (1997) Cellular and molecular neuroscience of alcoholism. Physiol Rev 77:1-20.

Dohrman DP, Diamond I, Gordon AS (1996) Ethanol causes translocation of cAMP-dependent protein kinase catalytic subunit to the nucleus. Proc Natl Acad Sci USA 93:10217-10221.

Dole VP, Gentry RT (1984) Toward an analogue of alcoholism in mice: scale factors in the model. Proc Natl Acad Sci USA 81:3543-3546.

Glantz SB, Amat JA, Rubin CS (1992) cAMP signaling in neurons: patterns of neuronal expression and intracellular localization for a novel protein, AKAP 150, that anchors the regulatory subunit of cAMP-dependent protein kinase II beta. Mol Biol Cell 3:1215-1228.

Goodwin SF, Del Vecchio M, Velinzon K, Hogel C, Russell SR, Tully T, Kaiser K (1997) Defective learning in mutants of the Drosophila gene 
for a regulatory subunit of cAMP-dependent protein kinase. J Neurosci 17:8817-8827.

Guthrie CR, Skalhegg BS, McKnight GS (1997) Two novel brainspecific splice variants of the murine Cbeta gene of cAMP-dependent protein kinase. J Biol Chem 272:29560-29565.

Hemmings BA (1986) cAMP mediated proteolysis of the catalytic subunit of cAMP-dependent protein kinase. FEBS Lett 196:126-130.

Huang YY, Kandel ER, Varshavsky L, Brandon EP, Qi M, Idzerda RL, McKnight GS, Bourtchouladze R (1995) A genetic test of the effects of mutations in PKA on mossy fiber LTP and its relation to spatial and contextual learning. Cell 83:1211-1222.

Kandel ER, Schwartz JH (1982) Molecular biology of learning: modulation of transmitter release. Science 218:433-443.

Kemp BE, Graves DJ, Benjamini E, Krebs EG (1977) Role of multiple basic residues in determining the substrate specificity of cyclic AMPdependent protein kinase. J Biol Chem 252:4888-4894.

Kiefer SW, Bice PJ, Orr MR, Dopp JM (1990) Similarity of taste reactivity responses to alcohol and sucrose mixtures in rats. Alcohol 7:115-120.

Kurtz DL, Stewart RB, Zweifel M, Li T-K, Froehlich JC (1996) Genetic differences in tolerance and sensitization to the sedative/hypnotic effects of alcohol. Pharmacol Biochem Behav 53:585-591.

McKnight GS (1991) Cyclic AMP second messenger systems. Curr Opin Cell Biol 3:213-217.

Moore MS, DeZazzo J, Luk AY, Tully T, Singh CM, Heberlein U (1998) Ethanol intoxication in Drosophila: genetic and pharmacological evidence for regulation by the cAMP signaling pathway. Cell 93:997-1007.

Ortiz J, Fitzgerald LW, Charlton M, Lane S, Trevisan L, Guitart X, Shoemaker W, Duman RS, Nestler EJ (1995) Biochemical actions of chronic ethanol exposure in the mesolimbic dopamine system. Synapse 21:289-298.
Ryabinin AE, Criado JR, Henriksen SJ, Bloom FE, Wilson MC (1997) Differential sensitivity of c-Fos expression in hippocampus and other brain regions to moderate and low doses of ethanol. Mol Psychiatry 2:32-43.

Schuckit MA (1986) Biological markers in alcoholism. Prog Neuropsychopharmacol Biol Psychiatry 10:191-199.

Schuckit MA (1988) Reactions to alcohol in sons of alcoholics and controls. Alcohol Clin Exp Res 12:465-470.

Schuckit MA (1994) Low level of response to alcohol as a predictor of future alcoholism. Am J Psychiatry 151:184-189.

Self DW, Nestler EJ (1995) Molecular mechanisms of drug reinforcement and addiction. Annu Rev Neurosci 18:463-495.

Skoulakis EM, Kalderon D, Davis RL (1993) Preferential expression in mushroom bodies of the catalytic subunit of protein kinase A and its role in learning and memory. Neuron 11:197-208.

Taiwo YO, Levine JD (1991) Further confirmation of the role of adenyl cyclase and of cAMP-dependent protein kinase in primary afferent hyperalgesia. Neuroscience 44:131-135.

Thiele TE, Marsh DJ, Ste. Marie L, Bernstein IL, Palmiter RD (1998) Ethanol consumption and resistance are inversely related to neuropeptide Y levels. Nature 396:366-369.

Villacres EC, Wong ST, Chavkin C, Storm DR (1998) Type I adenylyl cyclase mutant mice have impaired mossy fiber long-term potentiation. J Neurosci 18:3186-3194.

Wong ST, Athos J, Figueroa XA, Pineda VV, Schaefer ML, Chavkin CC, Muglia LJ, Storm DR (1999) Calcium-stimulated adenylyl cyclase activity is critical for hippocampus-dependent long-term memory and late phase LTP. Neuron 23:787-798.

Yoshimura M, Tabakoff B (1999) Ethanol's actions on cAMP-mediated signaling in cells transfected with type VII adenylyl cyclase. Alcohol Clin Exp Res 23:1457-1461. 